\title{
Occurrence and control of $N$-nitrosodimethylamine in water engineering systems
}

\author{
Yongning Bian ${ }^{1,2^{*}}$, Chuang Wang ${ }^{12^{*}}$, Guocheng Zhu ${ }^{1,2,3^{\dagger}}$, Bozhi Ren ${ }^{1}$, Peng Zhang ${ }^{2}$, \\ Andrew S. Hursthouse ${ }^{1,4}$ \\ ${ }^{1}$ Hunan Provincial Key Laboratory of Shale Gas Resource Utilization, Hunan University of Science and Technology, Xiangtan 411201, China \\ ${ }^{2}$ College of Civil Engineering, Hunan University of Science and Technology, Xiangtan 411201, China \\ ${ }^{3}$ School of Resource Environment and Safety Engineering, Hunan University of Science and Technology, Xiangtan 411201, China \\ ${ }^{4}$ School of Science \& Sport, University of the West of Scotland, Paisley PA1 2BE, UK \\ "These authors contributed equally to this work.
}

\begin{abstract}
$N$-nitrosodimethylamine (NDMA) is a typical nitrogen disinfection by-product, which has posed a potential threat to human health during drinking water disinfection. Because of the well-known effects of mutagenesis, carcinogenesis and teratogenesis, the high detection rate in water engineering systems (such as coagulation, membrane filtration and biological systems), and difficulty to remove, it has received wide concern in the field of water engineering systems. The NDMA is a low molecular weight hydrophilic organic substance, which is difficult to remove. Also, the mechanism for NDMA formation is also recognized to be complex, and many steps still needed to be further evaluated. Therefore, the mechanistic knowledge on NDMA formation potential and their removal processes is of particularly interest. Few papers summarize the occurrence and control of NDMA in water engineering systems. It is for this reason that the content of this paper is particularly important for us to understand and control the amount of NDMA thus reducing the threat of disinfection by-products to drinking water. Four parts including the mechanisms for the NDMA formation potential, the factors affecting the NDMA formation potential, the technologies for removal of NDMA are summarized. Finally, some definite suggestions are given.
\end{abstract}

Keywords: Disinfection by-products, Natural organic matter, $N$-nitrosodimethylamine, Water

\section{Introduction}

Drinking water disinfection is an important step in guaranteeing good water quality and consumer safety. It is a process which is used to kill the pathogenic microorganisms in water, and prevent the outbreak and spread of many diseases [1-3]. Chlorine-based disinfection is one of the most widely used methods for water treatment plants $[4,5]$. The observation of numerous disinfection by products (DBPs) (e.g. trihalomethanes (THMs), haloacetic acid (HAAs)) with known effects of mutagenesis, carcinogenesis and teratogenesis, a variety of alternative single or combined processes for replacement of disinfectants have appeared [6-10]. Among them, the use of chloramine disinfection dominates and aims to reduce the generation of THMs and HAAs
[11-14]. However, it was found that the use of a large number of chloramine disinfection products has produced more harmful nitrogenous disinfection byproducts $\left(\mathrm{N}-\mathrm{DBP}_{\mathrm{S}}\right)$ [15-17]. Because the content of the lower abundance of nitrogeous compounds in the aquatic environment, detection is challenging [18-20], $\mathrm{N}$-DBPs have previously not received wide attention. Recently, $\mathrm{N}$-DBPs have become of interest, particularly in understanding their formation and the removal effect by selected water treatment processes [21-23].

$\mathrm{N}$-DBPs include the flowing four sub-categories: nitrosamines (NAMs), haloacetonitriles (HANs) and the halogenated nitromethane (HNMs) and halogen ethylene amide (HAcAms) [24, 25]. The NAMs are a new type of DBPs including HANs and HNMs, which have a higher mutagenic activity and higher carci-
This is an Open Access article distributed under the terms of the Creative Commons Attribution Non-Commercial License (http://creativecommons.org/licenses/by-nc/3.0/) which permits unrestricted non-commercial use, distribution, and reproduction in any medium, provided the original work is properly cited.

Copyright (C) 2019 Korean Society of Environmental Engineers
Received January 9, 2018 Accepted May 5, 2018

${ }^{\dagger}$ Corresponding author

Email: zhuguoc@hnust.edu.cn,zgc945ahhn@163.com

Tel: +86-731-58290269 Fax: +86-731-58290269

ORCID: 0000-0002-7423-7276 
nogenic activity [26, 27]. Nine species of NAMs have been detected in drinking water, which are $N$-nitrosodimethylamine (NDMA), nitrosomethylethylamine (NMEA), nitrosodiethylamine (NDEA), nitrosodi-npropylamine (NDPA), nitrosodi-n-butylamine (NDBA), nitrosodiphenylamine (NDPhA), nitrosopyrrolidine (NPyr), nitrosopiperidine(NPip) and nitrosomorpholine (NMor), respectively [28, 29]. Toxicology studies showed that, NDMA could induce human organs to produce tumors [28]. The chronic toxicity of NDMA may lead to liver cancer, lung cancer, and also damage the nervous system [30]. In Canada, the maximum NDMA value for tap water reached $67 \mathrm{ng} / \mathrm{L}$ [31]. In China, $46.9 \mathrm{ng} / \mathrm{L}$ [32] has also been observed. In municipal water supply pipe, the maximum detection values of NDMA observed in different contries are also different, which range between 180 ng/L [31] in Canada, and 78.93 ng/L [33] in China. In the swimming pool and hot bathing waters, NDMA can be detected from substances produced in water treatment plants using the combined chlorine for disinfection [17]. In some water plants using ion exchange treatment processes, NDMA can also be detected [17].

The content of NDMA in the wider aquatic environment has also been studied. NDMA can cause cancer, mutation, and distortion in humans and animals [34]. Corresponding to $1 \times 10^{-6}$ level, the carcinogenic risk limit concentration for NDMA is $0.7 \mathrm{ng} / \mathrm{L}$, and that for THMs is $6 \mu \mathrm{g} / \mathrm{L}[35,36]$. The standard regulatory limit for NDMA concentration is not uniform across many regions. The regulatory level provided by both health services department of California State in United States and in Germany is less than $10 \mathrm{ng} / \mathrm{L}$ NDMA in dringking water [37]. The office of health and environmental assessment requires that the NDMA corresponding to public health standard in dringking water is $3 \mathrm{ng} / \mathrm{L} \mathrm{[37].} \mathrm{The} \mathrm{department} \mathrm{of} \mathrm{the} \mathrm{environment} \mathrm{and}$ energy, Ontario, Canada, suggest the NDMA lower than $9 \mathrm{ng} / \mathrm{L}$ [37]. The NDMA regulatory level that is provided by world health organization and Australia is $100 \mathrm{ng} / \mathrm{L}$ [38]. Although the concentration limit of NDMA in drinking water is not uniform, but in order to protect the water quality and safety, it is an important task for water treatment workers to reduce the content of NDMA in drinking water.

The understanding for the NDMA formation mechanism is an important theoretical basis for controlling NDMA. In the aquatic environment, the formation of NDMA is influenced by many interrelated factors. This paper reviews the formation mechanism of NDMA, as well as parameters affecting and controlling the NDMA formation, in order to reduce the NDMA. Recommendations are made to provide technical support and theoretical guidance for researchers and practitioners involved in protecting water quality and safety.

\section{Mechanisms for NDMA Formation}

The yield of NDMA resulting from dimethylamine (DMA) chlorination only accounts for $0.6 \%$ of the total yields of that by from standard water chlorination [39]. Furthermore, the formation of DMA under natural conditions may produce natural photolysis and biodegradation. Therefore, the DMA is not likely to be the primary precursor of NDMA in wastewater effluent and surface waters. The structure of the DMA is simple but it is an effective precursor for NDMA formation. Therefore, during the discussion of the mechanism for NDMA formation, DMA is still as the important modeling precursor [40-44]. In the mechanisms for the NDMA formation, those precusors containing a DMA group are subject to dealkylation, generating DMA following reaction with $\mathrm{HClO}, \mathrm{NH}_{2} \mathrm{Cl}$ and $\mathrm{NHCl}_{2}$. Subsequently, the DMA is oxidized into NDMA. In general, NDMA formation is often achieved through two pathways: one is nitrosation and the other is the action of asymmetric N, N-Dimethylhydrazine $(\mathrm{NDMH})$. The primary difference between two pathways is that during the transformation of DMA into NDMA, the introduction of $\mathrm{N}$ is different. For nitrosation pathway, the introduction of $\mathrm{N}$ can be achived via $\mathrm{HNO}_{2}, \mathrm{NO}_{2}^{-}, \mathrm{NO}_{3}^{-}, \mathrm{N}_{2} \mathrm{O}_{3}, \mathrm{~N}_{2} \mathrm{O}_{4}$ and hydroxylamine alone or synergistic action, while for unsymmetrical dimethylhydrazine (UDMH) action, it is mainly through inorganic chloramines.

\subsection{Conventional Nitrosation}

Nitrosation mainly refers to the reaction of amines such as DMA with nitrous acid to generate NDMA [45]. Lü et al. [46] studied the influence of cis and trans-configuration of $\mathrm{HNO}_{2}$ in the DMA reacting with $\mathrm{HNO}_{2}$ to form NDMA in conjunction with quantum chemical calculations. The main reaction process is that two molecules $\left(\mathrm{HNO}_{2}\right)$ are firstly transformed into $\mathrm{N}_{2} \mathrm{O}_{3}$, and thereafter, $\mathrm{N}_{2} \mathrm{O}_{3}$ reacts with DMA to form NDMA. Some of $\mathrm{N}_{2} \mathrm{O}_{3}$ are able to generate other intermediates before NDMA formation. The $\mathrm{HNO}_{2}$ is likely to produce species such as $\mathrm{NO}^{+}$and $\mathrm{N}_{2} \mathrm{O}_{3}$, and they can react with DMA to form NDMA [16, 34]. Mitch et al. [16] showed that less than $10^{-21} \mathrm{~g} / \mathrm{L}$ NDMA would be generated by reaction of $100 \mu \mathrm{M} \mathrm{NO}_{2}^{-}$and $100 \mu \mathrm{M}$ DMA for $24 \mathrm{~h}$ at $\mathrm{pH}=7$. For most natural waters or treated in drinking water plants, the $\mathrm{pH}$ is around 7 and therefore conventional nitrosation appears to contribute little to NDMA formation. During the synthesis of NDMA in laboratory studies, controlling $\mathrm{pH}$ to an appropriate range could promote the reaction of dimethylamine hydrochloride with the $\mathrm{NaNO}_{2}$ to generate the NDMA. The equation for the reaction is as follows [47].

$\left(\mathrm{CH}_{3}\right)_{2} \mathrm{NH} \cdot \mathrm{HCl}+\mathrm{NaNO}_{2}=\left(\mathrm{CH}_{3}\right)_{2} \mathrm{~N} \cdot \mathrm{NO}+\mathrm{NaCl}+\mathrm{H}_{2} \mathrm{O}(1)$

That is

$$
\left(\mathrm{CH}_{3}\right)_{2} \mathrm{NH}+\mathrm{HONO}=\left(\mathrm{CH}_{3}\right)_{2} \mathrm{~N} \cdot \mathrm{NO}+\mathrm{H}_{2} \mathrm{O}
$$

Sun et al. [48] indicated that: the trimethylamine (TMA) can be transformed into NDMA via nitrosation. During the transformation, TMA was transformed into the iminium ion. The iminium ion was then transformed into NDMA through three pathways. First, the iminium ion was hydrolyzed into DMA and then the NDMA was formed with DMA via nitrosation. Second, the NDMA was generated by decomposition and transformation of the intermediate products resulting from the reaction between iminium ion and $\mathrm{NO}_{2}^{-}$. Third, the iminium ion reacted with $\mathrm{N}_{2} \mathrm{O}_{3}$ to give NDMA. 


\subsection{Enhanced Nitrosation}

Choi et al. [49] suggest that HClO can promote the formation of DMA to generate NDMA through nitrosation reaction during chlorine disinfection. This study showed that the formation of NDMA speed under conexistence of DMA, nitrite and HClO in the same system was very fast at $\mathrm{pH}$ 7. Within reaction of one hour, the NDMA amount had reached the maximum. Andrzejewski et al. [50] suggested that an ozonation of DMA would result in NDMA. Its yields were low (less than $0.4 \%$ relative to DMA) and it could increase with the increase of $\mathrm{pH}$. The exposed times, ozone/DMA ratios, and free radical scavengers were other variables that affected the yield. The ozonation by-products indicated that nitrosation of DMA was possible pathway of nitrosamine formation. NDMA could be considered as a by-product of the ozonation of DMA in water, which was formed within a specific but reasonable ozone/DMA ratio range.

\subsection{UDMH Pathways}

Mitch et al. and Choi et al. [16, 17, 50, 51] studied the formation mechanism for NDMA in detail, suggesting that UDMH is the intermediate product resulting in the NDMA formation process. During the reaction, the DMA reacted with $\mathrm{NH}_{2} \mathrm{Cl}$ generating the UDMH, and finally UDMH was oxdized into NDMA via $\mathrm{NH}_{2} \mathrm{Cl}$. The process of UDMH formation belongs to alkaline catalytic reaction. If the reaction occurred under neutral condition, it would obtain the maximum yield of NDMA while the NDMA formation needed a long time [51]. The above theory has been demonstrated through the fact that the NDMA content in water distribution network is much higher than that in the effluent from water plants [52, 53].

In the water containing ammoniacal nitrogen under action of free chlorine, the NDMA may be produced via UDMH pathway. For those water sources without ammonia nitrogen, the yield of NDMA formation by the $\mathrm{NH}_{2} \mathrm{Cl}$ disinfection was significantly higher that that by the HClO disinfection alone [54]. The primary reason for the increase is that the generation of the stable chloride dimethylamine (CDMA) as a result of a fast reaction of $\mathrm{HCl}$ with DMA with a reaction constant of $6.1 \times 10^{7} \mathrm{M}^{-1} \cdot \mathrm{s}^{-1}$. Because $\mathrm{NH}_{2} \mathrm{Cl}$ and CDMA are stable pro-electric substances, the NDMA generation would be inhibited [54].

\subsection{Cl-UDMH Pathway}

1, 1-dimethylhydrazine can be oxdized into various substances by $\mathrm{NH}_{2} \mathrm{Cl}$, such as $\mathrm{N}$, N-Dimethylformamide and dimethyl cyanamide. Among them, the rate of NDMA transformation accounted for about 5\%. In addition, the generation of NDMA by UDMH was low. Therefore, there may be a more effective NDMA formation mechanisms than the UDMH approach [16]. Schreiber et al. [55] identified the UDMH chlorination pathway, called Cl-UDMH, suggesting that the concentration of dichloramine and dissolved oxygen were the key parameters determining amount of NDMA formation. The Cl-UDMH pathway includes the routes that the reaction between $\mathrm{NHCl}_{2}$ and DMA first generated Cl-UDMH, and then the product was oxidized into NDMA. A set of experiments demonstrated that the Cl-UDMH intermediate could explain most of NDMA formation process [56].

\subsection{Chloramination Pathway}

Partial $\mathrm{NHCl}_{2}$ formation significantly enhanced NDMA formation during chloramination [55]. Nonetheless, the predominance of $\mathrm{NH}_{2} \mathrm{Cl}$ under typical chloramination conditions might foster UDMH formation [56]. In addition to chlorination plus ammonia strategy and chlorination at breakpoints, pre-chlorination of pre-chlorinated source water can also be used to reduce the formation of NDMA; when chlorination time was increased before addition of ammonium chloride to the solution, NDMA formation from polyamine and polyDADMAC decreased during in situ chloramination [57]. Considering the high conversion of ranitidine to NDMA, the use of chloramine as a disinfectant for ranitidine wastewater can lead to the formation of important NDMA [58].

\section{6. $0_{3}$ Pathway}

Ozone $\left(\mathrm{O}_{3}\right)$ has been widely used in water treatment due to its highly effective disinfection [59-63], decolorization [64-66] and deodorant [67]. NDMA was found to occur in deionized water containing DMA after the addition of $\mathrm{O}_{3}$ and with the increase of $\mathrm{pH}$, its yield increased [50]. Experimental studies oxidizing eight substances using $\mathrm{O}_{3}$ indicated that those materials that contained the DMA group were the precursors of NDMA and the presence of the $\mathrm{NO}_{2}^{-}$could improve its production [68]. During oxidization by $\mathrm{O}_{3}$, the hydroxyl radicals can cause NDMA decomposition and two kinds of reaction then take place, in which the reaction trend was detemined by the structure of oxidized material and the $\mathrm{pH}$ value [68]. A mechanism for DMA oxdization into NDMA by $\mathrm{O}_{3}$ [54] indicated that the hydroxylamine might be the inorganic precursor of NDMA. Therefore there are three possible mechanisms for NDMA formation. The first one is that the precursor of the secondary amines and hydroxylamine react to form asymmetric two alkyl hydrazine intermediates, which are subsequently oxidized into nitrosamines substences through $\mathrm{O}_{3}$. Taking NDMA formation by DMA as an example, the DMA may react with the hydroxylamine to form UDMH and subsequently oxidized into NDMA (see Eq. (3)-(4)). The second is that the hydroxyl radical produced by $\mathrm{O}_{3}$ hydrolysis react with $\mathrm{NO}_{2}^{-}$generate $\mathrm{NO}_{2} \bullet$, by which the $\mathrm{N}_{2} \mathrm{O}_{4}$ generated oxdizes the DMA into NDMA (see the enhanced nitrosation shown in Eq. (5)-(7)). The last one is that the NDMA formation by those HCHO compounds generated during the oxidation of organic matter by $\mathrm{O}_{3}$ when DMA is available (enhanced nitrosation [50]).

$$
\begin{aligned}
\mathrm{NH}_{2} \mathrm{OH}+\left(\mathrm{CH}_{3}\right)_{2} \mathrm{NH} & \rightarrow\left(\mathrm{CH}_{3}\right)_{2} \mathrm{NNH}_{2}+\mathrm{H}_{2} \mathrm{O} \\
\left(\mathrm{CH}_{3}\right)_{2} \mathrm{NNH}_{2}+\mathrm{O}_{2} & \rightarrow\left(\mathrm{CH}_{3}\right)_{2} \mathrm{NNO}+\mathrm{H}_{2} \mathrm{O} \\
\mathrm{OH} \bullet+\mathrm{NO}_{2}^{-} & \rightarrow \mathrm{NO}_{2} \bullet+\mathrm{OH}^{-} \\
2 \mathrm{NO}_{2} \bullet & \leftrightarrow \mathrm{N}_{2} \mathrm{O}_{4} \\
\left(\mathrm{CH}_{3}\right)_{2} \mathrm{NH}+\mathrm{ONONO}_{2} & \rightarrow\left(\mathrm{CH}_{3}\right)_{2} \mathrm{NNO}+\mathrm{HONO}_{2}
\end{aligned}
$$




\section{Factors Affecting NDMA Formation}

\subsection{Disinfectants}

Commonly used disinfection methods for dringking water often include the use of chlorination, chloramine, $\mathrm{ClO}_{2}$ and $\mathrm{O}_{3}$ disinfection [69]. There are great differences in the mechanisms for NDMA formation by the precursors derived from different disinfectants [16]. The route from chloramine disinfection has been considered to produce the highest NDMA, followed by chlorination [16], in which the yields of NDMA by reaction between $\mathrm{NHCl}_{2}$ and DMA were higher than that from $\mathrm{NH}_{2} \mathrm{Cl}$ and DMA $[55,56]$. The route via $\mathrm{O}_{3}$ disinfection because of the relatively small, the amount of NDMA generated is relatively limited. In recent years, there are also reports on the generation of NDMA by $\mathrm{ClO}_{2}[70,71]$. Mitch et al. [72] showed that the yields of NDMA by the NaClO disinfection were less than that by the chloraminated route and the results of NDMA precursor analyses and dimethylamine analyses on those waters from two surface waters and two wastewater treatment plant process units. Chen et al. [73] showed that the phenylurea herbicide diuron might be an NDMA precursor, which formed NDMA under varied chlorine and chloramine conditions. The degree of NDMA generation with viarous disinfectants in an ascending order was as follows: $\mathrm{ClO}^{-}<\mathrm{NH}_{2} \mathrm{Cl}<\mathrm{NHCl}_{2}$. Charrois et al. [74] quantified NDMA of two full-scale chloraminating water treatment plants in Alberta between 2003 and 2005 and conducted bench-scale chloramination/breakpoint experiments to assess NDMA formation. It was shown that the ratio of $\mathrm{Cl}$ to $\mathrm{NH}_{3}-\mathrm{N}$ was a significant parameter affecting NDMA formation. The molar ratio in the range of $0.6: 1$ to $0.8: 1$ could produce the highest yield. Farre et al. [75] indicated that the simultaneous introduction of $\mathrm{NHCl}_{2}$ also had an impact on NDMA output; pre-prepared $\mathrm{NHCl}_{2}$ could generate more NDMA than the online NDMA formation. The NDMA formation by $\mathrm{O}_{3}$ and DMA indicated that with the increase of the $\mathrm{O}_{3}$ dosage, the NDMA yield increased and even presented a linear relationship with the $\mathrm{O}_{3}$ dosage [54]. The NDMA yield was greater with a combination of $\mathrm{O}_{3}$ and $\mathrm{NaClO}$, than that with $\mathrm{O}_{3}$ alone. Lee, et al. [76] showed that the combination of $\mathrm{NaClO}$ and $\mathrm{O}_{3}$ also had more positive effect in NDMA formation than $\mathrm{O}_{3}$ alone. It would be attributed to the $\mathrm{O}_{3}$ pretreatment which possibly resulted in the release of the DMA from relevant substances and subsequently generated NDMA during further $\mathrm{NaClO}$ disinfection. Applying eleven kinds of disinfection to seven different surface waters, Zhao et al. [70] showed that the amount of NDMA formed by the chloramine disinfection alone was higher than that by the chlorination. Environmental concentrations and mixtures of unknown nitrosamine precursors in source waters can form NDMA and other nitrosamines. In chlorine-based water treatment, Ranitidine (RNT) has been an important tertiary amine precursor of NDMA. Mingizem et al. [77] examined the effects of nitrite ions on the kinetics of NDMA formation during the chloramination of RNT with variable dissolved oxygen (DO), $\mathrm{RNT}, \mathrm{NH}_{2} \mathrm{Cl}, \mathrm{NO}_{2}^{-}$or $\mathrm{NO}_{3}^{-}$ and $\mathrm{pH}$. In the absence of the $\mathrm{NO}_{2}^{-}$, the molar yield of NDMA after $6 \mathrm{~h}$ of reaction was primarily influenced by $\mathrm{DO}$ and $\mathrm{pH}$, and marginally affected by initial $\mathrm{RNT}$ and $\mathrm{NH}_{2} \mathrm{Cl}$.

\subsection{Reaction Conditions}

The reaction variables significantly affecting NDMA generation include $\mathrm{pH}$, temperature and time [78-80]. The best $\mathrm{pH}$ for NDMA generation by UDMH and by enhanced nitrosation is different [17]. During NDMA formation by UDMH, the main influences include the form of inorganic chloramines, proportion and reaction rate [34]. The best $\mathrm{pH}$ for nitrasation to form NDMA was condiered to be 3.4 and under neutral and alkaline conditions, the reaction was slow [34]. Andrzejewski et al. [81] indicated that the NDMA yield by the reaction of $\mathrm{NO}_{2}^{-}$with DMA decreased with the increase of $\mathrm{pH}$. The highest NDMA formation could be achieved between $\mathrm{pH} 7$ and 8 through disinfection of water or sewage containing dimethylamine, ammonia and chlorine [82]. The results also suggested that the generation of UDMH and other intermediate products were largely affected by $\mathrm{pH}$, and that at $\mathrm{pH} 6-8$, it could reach the maximum of NDMA generation [16, 17, 51], which was consistent with that obtained by Mitch et al. [72]. The non-protonated DMA could react with $\mathrm{NHCl}_{2}$, resulting in maximum NDMA FP [56]. With either $\mathrm{NH}_{2} \mathrm{Cl}$ or $\mathrm{NHCl}_{2}$ and DMA at $\mathrm{pH}$ 6-11, the NDMA achieved the maximum at $\mathrm{pH}$ 8-10 for $2 \mathrm{~h}$ of reaction [56]. Another study showed that those such as DMA, diuron and ranitidine after chloramine disinfection test in the range of $\mathrm{pH} 7$ to 9 could generate the maximum amount of NDMA [16, 58, 83]. The reaction temperature could lagely influene the chloramine species as well as the reaction rate. A low temperature could reduce molecular collision, possibly leading to a reduction in the level of the reaction rate; however, a relatively higher temperature would cause a monochloramine decomposition or an unstable volatilization. Farre et al. [75] used three kinds of models to investigate the NDMA yield through $\mathrm{NHCl}_{2}$ disinfection, which was found the yields of the NDMA low than $10 \mathrm{ng} / \mathrm{L}$ for $6 \mathrm{~h}$ of disinfection. Overall, according to the need for disinfection and water protection, adjusting the dosing position of disinfectant and time interval can effectively control NDMA generation.

\subsection{Precursors}

Research on the classification and characteristics of NDMA precursors in the water environment are beneficial to the analysis of formation mechanism, effective regulation and removal from the water environment. The previous research has indicated that the NDMA precursors include the inorganic compounds (such as $\mathrm{N}_{2} \mathrm{O}_{3}, \mathrm{NH}_{2} \mathrm{Cl}, \mathrm{NHCl}_{2}$, hydroxylamine, etc.) and a range of organic compounds [57, 84-89].

\subsubsection{DMA}

The dimethylamine (DMA, $\left.\mathrm{HN}\left(\mathrm{CH}_{3}\right)_{2}\right)$, and tertiary amines containing DMA group and quaternary ammonium compounds, and those polymers containing DMA groups have been considered to be the most direct and effective precursors of NDMA [90-93]. Some materials such as primary amine, amino acid, dimethylamino compounds, proteins and other nitrogenous substances cannot generate detectable NDMA [94]. Those organic coagulants containing DMA group in water purification process and the strong anion exchange resin containing amine can produce a large amount of NDMA during the disinfection process, which 
are also considered as the precursors of NDMA [95]. Kemper et al. [91] indicated that the soap containing quaternary amine monomer, mouthwash shampoo containing quaternary amine polymer, and commercial detergents have the potential to generate NDMA, but the yield was less than 1\%. Le et al. [58] systematically studied the formation potential of NDMA (NDMA FP) from three pesticides (diuron, isoproturon, trifluralin) and five kinds of drugs (ranitidine, doxepin, amitriptyline, mifepristone, minocycline). Eight kinds of medications containedof the DMA group, among them four of the medications had higher NDMA FP than DMA. Ranitidine at $\mathrm{pH} 7.9$ had a 59.6\% molar yield of NDMA. Shen et al. [96] studied 18 kinds of drugs containing DMA group, and found that the molar NDMA yields of 8 kinds of drugs were only above $1 \%$.

\subsubsection{DOM}

Mitch et al. [97] confirmed that with DMA under the action of chloramine, the therotical formation of NDMA content was far below that detected in real water, suggesting that there must be other NDMA precursors existing in the water environment. Natural organic matter (NOM) has been taken into account as a heterogeneous mixture of the organics. The concentration of dissolved organic nitrogen (DON) is much higher than the detection limit for NDMA in water [83]. Chen et al. [98] separated the DOM from the river water into different fractions and after chloramination, the NDMA FP of the fractions were examined (see Table 1). Among them, the hydrophilic base (HPIB) had the highest NDMA FP. As the DOC content of the hydrophobic acid (HPOA) is up to $72 \%$, the HPOA should have significant contribution to the formation of NDMA

Among the seven different water sources, three components of NDMA FP were identified and average values were listed in descending order as the hydrophilic component (HPI) of 23.8 $\mathrm{ng} / \mathrm{mgDOC}>$ transitional component (TPI) of $11.20 \mathrm{ng} / \mathrm{mg}$ DOC $>$ hydrophobic components (HPO) 4.95 ng/mgDOC. Combined with the study of Chen et al. [98], it can be concluded that the NDMA FP of the hydrophilic component was greater than that of the hydrophobic component; the NDMA FP of the alkaline component was greater than that of the acidic component; the hydrophilic alkaline component had the highest NDMA FP.

One of the most important sources of natural organic matter is the release of the algal organic matter (AOM). The AOM exists mainly in the form of the hydrophilic organic matter, which has great contributions to the formation of the NDMA [99, 100]. Li et al. [99] found that the Microcystis aeruginosa during exponential growth period had the NDMA FP of intracellular organic matter being $9.65 \mathrm{ng} / \mathrm{mgDOC}$ with NDMA FP of the extracellular organic matter being $18.91 \mathrm{ng} / \mathrm{mgDOC}$. The Microcystis aeruginosa often grows in the lakes, ponds and other water environments containing rich organic matter, so the eutrophic water is likely to have higher NDMA FP.

Those components which contained DMA materials and DON from the water body are the important precursors of NDMA. The main reasons for the differences in NDMA yields are attributed to variation in the concentration and the structural characteristics of DOM in the water resource. During the reaction of precursors with DMA, the formation of NDMA may be affected due to the concentration of individual precursors in the reaction process and relevant reaction rate [101]. Different precursors have different release characteristics for DMA, which can introduce different effects on the formation of DMA and the conversion of DMA to NDMA. This will affect the formation of NDMA. Junghoon et al. [17, 51] studied the reaction of DMA and $\mathrm{NH}_{2} \mathrm{Cl}$, and found that the generation of NDMA varied with DMA dosage and the maximum NDMA could be acchieved at the 1:1 molar ratio of $\mathrm{NH}_{2} \mathrm{Cl}$ to DMA, while the $\mathrm{NH}_{2} \mathrm{Cl}$ at a ratio $>1$ was overdosed and numorous NDMA could be generated via UDMH. At a ratio < 0.1, the DMA was relatively overdosed, thus generating CDMA while inhibiting NDMA formation. Therefore, the structure, molecular mass and concentration of the precursor and the release characteristics of DMA are an important influence on the formation of NDMA.

\subsection{Background Water Quality Parameters}

Water quality parameters had a significant influence in NDMA production, more specifically the inorganic nitrogen (e.g., $\mathrm{NH}_{4}{ }^{+}$, $\mathrm{NH}_{3}, \mathrm{NO}_{2}^{-}$and $\mathrm{NO}_{3}^{-}$), DON, bromide ion and dissolved oxygen concentration [16, 17, 70, 102].

The disinfection of DOM components showed that individual DOM components had a larger difference in the level of NDMA FP [83, 98, 99, 103]. DON was an important component of DOM in the water, which was found an important source of the precursor of N-DBPs [83]. Mantas et al. [104] showed that the sewage plant effluent free DON is the main precursor of NDMA. Lee et al. [105] undertook a NDMA FP test for different water samples, indcaiting that the yield of the NDMA increased as the DOC/DON value decreased. After the NDMA FP test, it was found that HPO had the smallest NDMA FP, and overall, research on the speciation and concentration level of DON and inorganic nitrogen parameters (including $\mathrm{NH}_{4}{ }^{+}-\mathrm{N}, \mathrm{NO}_{2}^{-}-\mathrm{N}$ and $\mathrm{NO}_{3}{ }^{-}-\mathrm{N}$ ) in water and their relationship between them and NDMA formation potential, are destined to be essential for exploration of mechanisms for N-DBPs.

\subsubsection{Inorganic nitrogen}

The $\mathrm{NO}_{2}^{-}, \mathrm{NO}_{3}^{-}$and other inorganic salts play a critical role during nitrosation. The best $\mathrm{pH}$ for nitrosation reaction was at 3.4 while between $\mathrm{pH} 6$ to 8 , there was lower NDMA formation

Table 1. NDMA FP of the Separated Components of DOM from the Rivers of lowa, USA [98]

\begin{tabular}{ccccccc}
\hline DOM & $\begin{array}{c}\text { Hydrophilic } \\
\text { acid (HPIA) }\end{array}$ & $\begin{array}{c}\text { Hydrophilic } \\
\text { neutrality (HPIN) }\end{array}$ & $\begin{array}{c}\text { Hydrophilic } \\
\text { base (HPIB) }\end{array}$ & $\begin{array}{c}\text { Hydrophobic } \\
\text { acid (HPOA) }\end{array}$ & $\begin{array}{c}\text { Hydrophobic } \\
\text { neutrality (HPON) }\end{array}$ & $\begin{array}{c}\text { Hydrophobic } \\
\text { base (HPOB) }\end{array}$ \\
\hline DOC contribution (\%) & 7.90 & 0.80 & 4.60 & 72.00 & 1.10 & 1.98 \\
NDMA FP (ng/mg DOC) & 43.50 & 25.76 & 77.50 & 27.47 & 22.44 & 31.43 \\
\hline
\end{tabular}




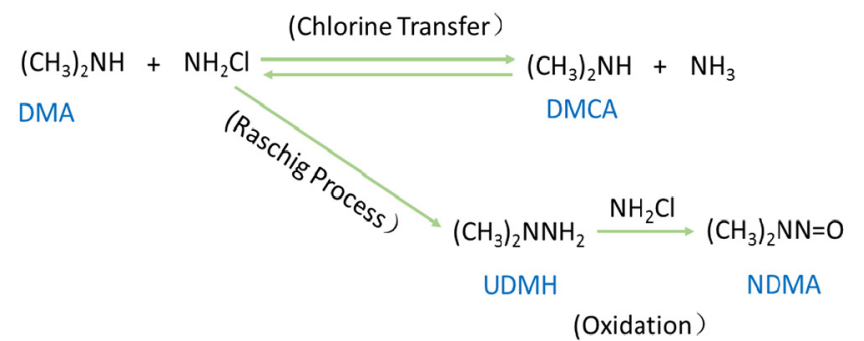

Fig. 1. Scheme for NDMA formation by DMA and $\mathrm{NH}_{2} \mathrm{Cl}$ [17].

in drinking water treatment. In the presence of $\mathrm{NH}_{3}$ and $\mathrm{NH}_{4}{ }^{+}$, the chloramine generated during chlorine disinfection in which NDMA is produced was via UDMH or Cl-UDMH. Using chloramine disinfection generates a higher quantity of NDMA, the presence of $\mathrm{NH}_{3}$ or $\mathrm{NH}_{4}{ }^{+}$rapidly converts DMA to NDMA because the presence of ammonia can control the hydrolysis of monochloramine.

Fig. 1 presents a scheme for NDMA formation by DMA and $\mathrm{NH}_{2} \mathrm{Cl}$ [17]. The NDMA was found to increase slightly with the decrease of ammoniacle nitrogen in the molar concentration range of $0.14-1.0 \mathrm{mmol} / \mathrm{L}(\mathrm{Cl} / \mathrm{N}$ molar ratio was in the range of 0.1 to 0.7 ) [17].

In the presence of the ammoniacle nitrogen in secondary effluent from wastewater treatment plants, the use of chlorine disinfection could yield up to $460 \mathrm{ng} / \mathrm{L}$ NDMA; however, only $20 \mathrm{ng} / \mathrm{L}$ could be generated in the absence of ammoniacle nitrogen [106].

\subsubsection{Organic nitrogen}

NDMA precursors are predominantly found in DON sources [102, 107-110]. NDMA formation is correlated with the ratio of DOC to DON (DOC/DON) [89, 105]. In general, the generation of NDMA is inversely proportional to the ratio. The contents of DON and DOC in the surface water source change with the seasonal temperature. DON concentration (0.02-0.17 mg/L) increased with the increase of water temperature $(6-22)(\mathrm{r}=0.77)$ [111]. In the winter dry season, despite the reduction of both the rain water and surface runoff, the treated industrial wastewater and domestic sewage and waste emissions did not change, which weaked the water dilution and self purification effects on lowing pollutants concentration thus resulting in the increase in the level of DOC and DON [112]. When the DOC/DON decreased, the formation of NDMA would be increased. Conversly, the formation of NDMA would reduce in summer wet-season.

\subsubsection{Bromine ion and dissolved oxygen}

The formation of NDMA can be influenced by the presence of the bromide ion and dissolved oxygen in a particular environment or the presence of specific substances. Bromide ion as a common trace component in drinking water can be rapidly oxidized by free chlorine and $\mathrm{NH}_{2} \mathrm{Cl}$. In the presence of an excess of $\mathrm{NH}_{3}$ or $\mathrm{NH}_{4}{ }^{+}$, the hypochlorite when added into water is able to generate the bromamines. The bromamines has similar chemical properties with chloramine, but has more chemical activity, thus it is more easily to interact with DMA to generate NDMA [113-115]. Only in the presence of bromide in the water, the N, N-Dimethylsulfamide (DMS) can be oxidized to form NDMA via the catalytic effect of ozone [116]. The dissolved oxygen in water plays a key role in the formation of NDMA in Cl-UDMH pathway [55, 56]. Under low oxygen concentration, the inhibition of NDMA formation by the reaction of the ranitidine with chloramine was significant [83]. Dissolved oxygen was also found an influential factor during the catalytic conversion of DMA to NDMA via the activated carbon [117].

\section{Technologies for Removal of NDMA}

The effective control of NDMA may be divided into four steps. First, conducting timely and effective analysis of trace NDMA in water is required, which is the basis for the effective control of NDMA. Second, the precursor of NDMA and others affecting NDMA formation needs to be effectively removed or controlled prior to disinfection. Third, during water treatment, the amount of NDMA is to be reduced by optimizing the disinfection process. Finally, with advanced treatments, removal of any NDMA formed can be carried out.

\subsection{Monitoring Methods}

Effective detection is an important for the effective control of NDMA. It can be divided into two parts including sample pretreatment and analysis. The detection and analysis were carried out by using combination of chromatography and mass spectrometry after the pretreatment of sample through extraction and enrichment. Due to the hydrophilic and strong polarity of NDMA, using a highly efficient sample preconcentration technique and high sensitivity detection method is the key the quantitative analysis of trace NDMA [118, 119].

The pretreatment of NDMA water samples can be used ascorbic acid or $\mathrm{Na}_{2} \mathrm{~S}_{2} \mathrm{O}_{3}$ to prevent the residual chlorine from reacting with DMA to generate NDMA, to eliminate the interference of the reaction to the detection of NDMA [120]. Given the NDMA degradation occurs under solar radiation [34], the water samples need to be stored at low temperature in the dark. The commonly used methods for extraction and enrichment include liquid-liquid extraction (LLE), solid-phase extraction (SPE) and solid phase micro extraction (SPME) [121, 122]. LLE method requires larger volumn of water sample and the extraction agent is generally toxic and volatile, in addition, sample recovery rate is not high $[16,123]$. Overall, it cannot reach the dringking water standard of NDMA detection in the ng/L level [16, 123]. It is for this reason that the LLE method is limited in practice. The SPME is a relatively recent development of sample pretreatment technology, which integrates sampling, extraction and concentration [124]. It can reduce blank values, shorten the pretreatment time and deliver the selective enrichment of the sample [124]. However, the SPME method is affected by many factors. Its detection limit is difficult to meet drinking water requirements (1-10 ng/L), thus it is more commonly applied to the monitoring of wastewater [125]. The SPE method is a more mature and effective method for the detection of trace NDMA, which has the advantages of being suited to large volumes of water sample, 
Table 2. Comparison of SPE and SPME [37, 125, 127, 128]

\begin{tabular}{cccccc}
\hline Method & Sample $(\mathbf{m L})$ & Organic solvents $(\mathbf{m L})$ & Time $(\mathbf{h})$ & Detection limit $(\mathbf{n g} / \mathbf{L})$ & Rate of recovery (\%) \\
\hline SPE & $250-1,000$ & $45-84$ & $1-5$ & $0.26-2$ & $71-110$ \\
SPME & $4.5-10$ & 0 & $0.5-1.5$ & $3.2-2,000$ & $46-259$ \\
\hline
\end{tabular}

convenient operation and only small amount of organic solvent. It is the latest NDMA standard detection method used in the United States and Canada [126]. There are many differences between SPME and SPE.

The combined use of chromatography and mass spectrometry (MS) is an important analytical tool, which benefits from the high sensitivity and strong qualitative capability of MS. Due to the low NDMA content in samples, it has higher sensitivity and specificity requirements for analysis. The traditional gas chromatography and thermal conductivity detector (GC/TCD) [129], GC and nitrogen-phosphorus detector (GC/NPD) [130] are difficult to meet these requirements for reliable trace detection. However, gas chromatography-mass spectrometry (GC/MS/MS, GC/MS) can show high sensitivity and accuracy [98, 131]. The most widely used method for determination of tracing NDMA is GC/MS/MS, which uses the selected ion monitoring mode (SIM) and the positive chemical ionization (PCI) as ion source [98, 131]. Liquid chromatography and mass spectrometry (LC/MS, LC/MS/MS) has a unique advantage for measuring those N-DBPs that have poor thermal stability, of which the NDMA detection limit proposed by the United States and Canada in 2007 was to $0.1-10.6 n g / L$ [126]. In the case of LC/MS/MS improved detection limits can reach lower than $2.5 \mathrm{ng} / \mathrm{L}[70,132]$.

There is no uniform standard method, which can quickly and accurately determine ng/L concentration NDMA. The existing methods can only rely on new instruments or related accessories to achieve the accuracy of detection [133-137]. The operation is complicated and not cost-effective. Therefore, it is necessary to optimize the NDMA detection method regarding the sample pretreatment procedure and the testing equipment. At present, there is an urgent need to develop new technology that is more accurate and convenient, as well as the rapid detection and real-time monitoring method without complex sample pretreatment. For NDMA sample pretreatment, new type or combination of solid phase extraction agent, or other strongly applicable, higher efficient and low cost pretreatment technologies needs to be developed. For NDMA analysis, it can also be considered to improve the operating performance and technical index of instrument by using the new technology in other scientific fields, and establish the standard method for determining NDMA.

\subsection{Precursor Removal}

According to generation mechanisms for NDMA, combined with the operation of water plant, source control is focused on removal of the NDMA precursors as well as the key substances (e.g., organic nitrogen compounds as DON and inorganic nitrogen compounds as ammoniacl nitrogen, nitrate and soluble nitrogenous salts) by optimizing conventional plant operation processes.

\subsubsection{Coagulation}

The DON component in the source water is complex, with a wide molecular weight range distribution, and most of them are 1-50 kD [138]. Conventional coagulation can remove the organic substances of molecular weight $>3 \mathrm{kD}$, while enhanced coagulation has a considerable removal efficiency for organic matter in the $0.5-3 \mathrm{kD}$ range [139-141]. As the DON is mainly hydrophilic, low molecular weight $(<1 \mathrm{kD})$ organic matter [83], the conventional treatment processes (e.g., coagulation, sedimentation, filtration and disinfection) find it difficult to remove [142-145]. From the analysis of molecular weight distribution, enhanced coagulation is likely to be the most effective approach in reducing DON.

The removal effect on DON by the conventional treatment process in 28 drinking water plants in the United States was statistically analyzed as shown in Table 3 [146]. The DON concentration of raw water was $0.2 \mathrm{mg} / \mathrm{L}$.

Table 3 showed that the removal efficiency of DON by conventional coagulation is lower than that of the combination of coagulant and cationic polymer, and the removal of DON after $\mathrm{O}_{3}$ is enhanced by biological filters. Previous research shows that the removal rate of $5 \%-20 \%$ can be improved by the combination of polymer and alum [146]. Using aluminum sulfate as coagulant for DON, the best removal rate of $30 \%-45 \%$ was achieved [146]. Li et al. [147] indicated that after pre ozonation, the DON removal efficiency by the conventional coagulation flocculation is maintained at around $20 \%$. The raw water of the Huangpu River in China was coagulated by the aluminum sulfate, of which the removal efficiency of DON was up to $35 \%$ with coagulant dosage of $100 \mathrm{mg} / \mathrm{L}$, while increasing the coagulant dosage the effect on removal is not obvious. The combined process of ozone and biologically activated carbon $\left(\mathrm{O}_{3} / \mathrm{BAC}\right)$ had a significant effect on the removal efficiency of DON, which can reach $60 \%$. Lee et al. [130] selected ferrate to pre-oxidize DMA and some materials containing DMA groups, suggesting that ferrate can effectively reduce the NDMA FP value. After reaction of $30 \mathrm{~min}$, except for DMA, the removal efficiency of NDMA FP of the other precursors were over 95\%. The pre oxidation of the NDMA precursor could decrease the NDMA FP during chloramine disinfection and $\mathrm{O}_{3}$ oxidation was more effective than $\mathrm{ClO}_{2}$ [76]. Enhanced coagulation improves the removal efficiency of DON

Table 3. Removal of DON by Conventional Treatment Process [146]

Process

DON removal efficiency (\%)

$\begin{array}{lc}\text { Conventional Coagulation } & 9 \\ \text { Coagulation + Cationic polymer } & 23 \\ \text { Biofilter with } \mathrm{O}_{3} & 34 \\ \text { Biofilter without } \mathrm{O}_{3} & 16\end{array}$

Biofilter without $\mathrm{O}_{3}$ 
to a certain extent, but the total removal was not satisfactory. The combined process of preoxidation and enhanced coagulation has a significant effect on lowering FP NDMA value. Therefore, research on new enhanced treatment technology should attract more attention on the application to drinking water treatment.

\subsubsection{Membrane treatment}

DON has a low molecular weight, polar characteristic [148]. The acid-base difference of DON is larger and the range of molecular mass distribution is wide. There is no obvious effect on removal of DON via conventional microfiltration (MF) and ultrafiltration (UF) membrane treatment technology [148]. Yeomin et al. [149] selected 6 kinds of reverse osmosis (RO) membrane and 2 kinds of nanofiltration (NF) membrane to study the raw water DON removal effect by membrane treatment and the influencing factors. The RO membrane had a pore size ranging from 0.33 to $0.35 \mathrm{~nm}$ and a normal pressure from 1,035 to 1,550 $\mathrm{kPa}$, and NF membrane pore size from $0.43-0.45 \mathrm{~nm}$ and a normal pressure from 518 to $690 \mathrm{kPa}$. The results showed that the average removal efficiency of 6 RO membrane (65\%) was higher than that of NF (50\%), suggesting that the removal effect of DON was related to the ratio of solute particle diameter to membrane pore size. In general, the ratio $(>0.8)$ implied a better removal efficiency of DON while it was difficult to remove DON with a smaller ratio $(<0.4)$ [149]. DON molecular weight and its structure characteristics are the main factors that affect the membrane treatment effect. Usually, those having the complex structure and charged molecules were easily removed. Tomaszewska et al. [148] studied the removal effect of the DON in 12 water treatment plants, which indicated that the combined process (coagulation/UF) had a larger impact on the DON removal, by which the removal efficiency was increased by nearly $45 \%$. The used coagulant (50-100 mg/L) was poly aluminium chloride (PAC), which could adsorb those DON small molecular components that have penetrated the ultrafiltration membrane. This also reduces the adhesion of pollutants on membrane thus reducing the membrane fouling [150]. The membrane also has better rejection effect on nitrate, nitrate and nitrogous salts. Overall, the membrane technology can effectively control the NDMA precursor and the inorganic nitrogen. How to improve DON rejection efficiency, control membrane fouling and reduce economic cost is one of the important contents of membrane industry development in the future.

\subsubsection{Disinfection control}

The yields of the NDMA could be reduced via disinfection process optimization. During disinfection process there is a need to avoid generating inorganic chloramines. In the presence of ammonia, using break point chlorination to determine chlorination dosage was effective for reducing NDMA formation [39]. When the chloramine disinfection is used or there is an unavoidable chloramine generation occuring, adjusting $\mathrm{Cl} / \mathrm{N}$ to one would reduce the NDMA yields [39]. Extending free chlorine contact time before dosing ammonia was able to effectively reduce NDMA formation in drinking water during chloramine disinfection [55]. For example, Charrois et al. [151] increased the free chlorine contact time of $30 \mathrm{~s}$ to $2 \mathrm{~h}$ before adding ammonia, finding that the
NDMA yields decreased from $180 \mathrm{ng} / \mathrm{L}$ to $5 \mathrm{ng} / \mathrm{L}$. The NDMA yields in the disinfection process increased rapidly in the first few hours, especially in the first $6 \mathrm{~h}$. There was few NDMA yields produced less than $10 \mathrm{ng} / \mathrm{L}$ [76]. Thus, according to actual needs of disinfection and water quality guarantee, adjusting disinfectant dosing position and time interval can effectively control the formation of NDMA.

\subsection{Removal of NDMA}

\subsubsection{Physical process}

NDMA is a pale yellow oily liquid, whose density is similar to water. It has a high solubility, belonging to low molecular weight hydrophilic organic material [39, 78, 152-154]. Because the octanol/water partition coefficient is low -0.57 [152], it is hard to bio-enrich or adsorb by particles during migration and transformation. In addition, removing NDMA from natural water via the evaporation and stripping is also difficult. The efficiency of physical removal is relatively low, but promising physical methods could be through adsorption and membrane process.

The physical and chemical properties of the NDMA make its adsorption on soil, activated carbon or other hydrophobic materials poor, while the hydrophilic materials (such as zeolite and Ambersorb572 resin) have stronger performance for NDMA adsorption. Kommineni et al. [155] compared adsorption effects of NDMA among a range of materials, and found that Ambersorb572 resin and shell derived activated carbon has good adsorption for NDMA, but the adsorption capacity is relatively low overall which potentially increases the processing costs. The NDMA concentration lower than $50 \mathrm{ng} / \mathrm{L}$ was also difficult to treat by adsorption. Dai et al. [156] selected Lignin and coconut shell as adsorbents, finding that the adsorption capacity for NDMA by activated carbon is much higher than that by molecular sieve. After modification, the polar functional groups were decreased, and the hydrophobic capacity of activated carbon was enhanced, and the NDMA with nonpolar methyl end was adsorbed in the pores. As a result, the amount of NDMA adsorption increases exponentially. In addition, solid surfaces containing aldehyde or ketone functional groups also contribute to the adsorption of NDMA. With the development of activated carbon fiber as adsorption material for adsorption of NDMA and modified activated carbon [157], the adsorption capacity of NDMA needs to be re-evaluated.

NDMA molecules are very small. Except for reverse osmosis, the ultrafiltration and nanofiltration processes have no effects on removal of them and in contrary, it would lead to an increase in the level of NDMA [157]. Reverse osmosis membrane can effectively remove secondary and tertiary amines from water, because they have a positive charge at neutral $\mathrm{pH}$. In the general water environment, NDMA does not hold charge so the removal efficiency of NDMA by reverse osmosis is not high [157]. Eva et al. [158] studied the effect of several kinds of RO membranes on the removals of seven types of alkyl nitrosamines containing the NDMA in deionized water. The results showed that as the molecular weight increased the better the interception of molecules and the removal efficiency of NDMA by the reverse osmosis membrane can reach up to 56\% - 70\%. Plummee et al. [157] 
used a membrane (EPSA2, HAIDELUN Com., USA) to remove NDMA in water treatment plants. It was observed that NDMA removal by RO (Hydranautics ESPA2, composite polyamide) at the Interim Water Purification Facility is between $24-56 \%$ and $59-75 \%$ was removed across RO and ultraviolet radiation (UV) treatment together [157]. It is noted that the characteristic variations of inlet water and polarization possibly leads to membrane fouling when the water passes through the membrane, which makes the removal efficiency of NDMA unstable.

\subsubsection{Chemical processes}

NDMA is sensitive to light and photochemical dissociation, thus photolysis is most widely used technique to remove NDMA, especially using UV photolysis. NDMA is able to strongly adsorp UV radiation within wavelength range of 200-275 nm and the strongest absorption band occurs at $227 \mathrm{~nm}$. It results in the electron transition from $\pi$ to $\pi^{*}$, followed by the broken of $\mathrm{N}$ - $\mathrm{N}$ key fracture [159]. The primary products resulting from the photolysis are DMA and $\mathrm{NO}_{2}{ }^{-}$salt and secondary products including $\mathrm{NO}_{3}^{-}$salt, HCHO and TMA [160-163]. The DMA is not further photodegraded but $\mathrm{NO}_{2}^{-}$salt can be oxidized to $\mathrm{NO}_{3}{ }^{-}$ salt [164]. Lee et al. [165] found that $\mathrm{pH}$ and dissolved oxygen have an influence on UV removal of NDMA. It is not effective when high water turbidity and chromophores or other chemicals interfere with short wavelength UV.

Sharpless et al. [166] made a comparison between degradation effect of low pressure mercury lamp (LP) and effect of medium pressure mercury lamp (MP) on removals of NDMA, it showed that the LP and MP had the same photon efficiency, and no relationship with the wavelength in the short-wave ultraviolet region was found. Xu et al. [167] showed that with UV degradation of NDMA for reaction of $5 \mathrm{~min}$, the NDMA was reduced up to $97.5 \%$. With lower $\mathrm{pH}$, enhanced illumination area and radiation intensity higher removal of NDMA occurred. At $\mathrm{pH} 2.2$, the NDMA has the maximum photodegradation rate. The UV removal efficiencies of NDMA in tap water and river water reached $96.7 \%$ and $94.8 \%$, respectively, which showed that the environmental conditions have an influence on NDMA degradation by photolysis. NDMA also has a second light absorption region between 300 and $350 \mathrm{~nm}$ where it produces a transition from $\pi$ to $\pi^{*}$, thus photolysis of NDMA can occur under sunlight [34]. Solar radiation is an important pathway in degradation of NDMA [34, 132]. Fan et al. [168] studied the effects of solar light and temperature on degradation of NDMA and N-diethylnitrosamine (NDEA), and found that $60.88 \mathrm{ng} / \mathrm{mL}$ of NDMA and $60.06 \mathrm{ng} / \mathrm{mL}$ of NDEA could be reduced to $10.88 \mathrm{ng} / \mathrm{mL}$ and $7.57 \mathrm{ng} / \mathrm{mL}$ for photolysis of $4 \mathrm{~h}$. Degradation by solar radiation appears to be time-consuming. Plumlee et al. [132] showed that with modeled natural light to observe photochemical decay of NDMA from surface water it showed a half-life period of NDMA to be $16 \mathrm{~min}$, the presence of light shielding and more DOC would delay the photolysis of NDMA. The half-life period of NDMA from the typical rivers and wetlands would take a few hours or a few days [132]. Therefore, the application of solar radiation to effectively degrade NDMA is important task in the future.

AOPs have received wide attention in the degradation of organ- ic matter [169], and processes assessed include UV, $\mathrm{O}_{3}, \mathrm{H}_{2} \mathrm{O}_{2}$, Fenton reagent, Fenton-like reagent, ultrasound and others. AOPs has been found to remove DBPs and the hydroxyl radical $(\cdot \mathrm{OH})$ produced in AOPs is an important factor affecting the removal efficiency of NDMA. Hiramoto et al. [170] used $\mathrm{Fe} / \mathrm{H}_{2} \mathrm{O}_{2}$ to degrade NDMA in phosphate buffer, showing a good removal efficiency, but the degradation of NDMA eventually produces NO, which is potentially damaging to DNA and protein molecules thus a threat to human health. The main drawback was that the $\mathrm{Fe} / \mathrm{H}_{2} \mathrm{O}_{2}$ was often used within strong acidic environment whilst the real water environment is often at $\mathrm{pH}$ 6-8.

There is considerable interest in the development of $\mathrm{O}_{3}$ oxidation [171]. The influence of $\mathrm{pH}$ on oxidation is significant: at neutral condition, the oxidation rate is $13 \%$ while at $\mathrm{pH} 8$, the oxidation rate was increased to $55 \%$ [171]. In the $\mathrm{O}_{3} / \mathrm{H}_{2} \mathrm{O}_{2}$ coupling process, the NDMA oxidation rate was about $85 \%$ at $\mathrm{pH}$ 7 and 8 , which significantly increased NDMA oxidation rate [171]. The main reason for the increase was that the $\mathrm{HO}_{2}^{-}$produced by $\mathrm{H}_{2} \mathrm{O}_{2}$ hydrolysis promoted the $\mathrm{O}_{3}$ to generate $\cdot \mathrm{OH}$, thereby increasing the oxidation rate of NDMA. In the $\mathrm{O}_{3} / \mathrm{UV}$ process, the $\mathrm{O}_{3}$ generated $\mathrm{H}_{2} \mathrm{O}_{2}$ in the presence of UV radiation [169], the subsequent reactions similar to those occuring in the $\mathrm{O}_{3} / \mathrm{H}_{2} \mathrm{O}_{2}$ process. The advantage of this process in addition to the increase in NDMA removal rate, includes degradation of NDMA by partial oxidation to DMA and the generation of $\mathrm{NO}_{3}$ salts [172], and a controable DMA yield [167, 173]. At $\mathrm{pH} 4$, the $\mathrm{UV} / \mathrm{H}_{2} \mathrm{O}_{2}$ had a better effect on removing NDMA with a degree close to $100 \%$ for reaction of $5 \mathrm{~min}$. Compared with $\mathrm{O}_{3}$ and UV alone the DMA yields were more controlable in the $\mathrm{UV} / \mathrm{H}_{2} \mathrm{O}_{2}$ process [174].

Catalytic metal reduction is also another method for degradation of NDMA, and can be a single metal catalysis system or double metal catalytic system, with the later appearing to be more efficient [175-177]. Frierdich et al. [175] applied porous $\mathrm{Ni}$ material with high specific surface area in catalytic reduction of NDMA. As a result, the NDMA was rapidly reduced to DMA and $\mathrm{N}_{2}$. However, $\mathrm{NO}_{3}{ }^{-}$salts can also be reduced by $\mathrm{Ni}$ material, which possibly influence the degradation of NDMA due to the competitive use of $\mathrm{Ni}$ material. Lai, et al. [176] applied the zero-valent $\mathrm{Fe}$ in catalytic reduction NDMA, which generated DMA and $\mathrm{NH}_{4}{ }^{+}$, for which the half-life is up to $13 \mathrm{~h}$. Matthew et al. [178] applied metal powder in catalytic $\mathrm{H}_{2}$ to reduce NDMA and form DMA. A Fe-Ni catalytic system to degrade NDMA $[176,177]$ showed Fe reduced water to monatomic hydrogen and subsequently reacted with Ni-excited NDMA producing DMA and $\mathrm{NH}_{4}^{+}[176,177]$. The half-life period of NDMA by Fe-Ni catalytic degradation was 2-20 min [176, 177]. The Fe-Ni system was not active or stable for long periods [176, 177]. A Pd-In catalytic system was applied in the removal of NDMA from drinking water, which was degraded into DMA and $\mathrm{NH}_{4}{ }^{+}$ [179]. The $\mathrm{H}_{2} \mathrm{~S}$ resulting from the raction of sulfate reducing bacteria and $\mathrm{H}_{2}$ have strong poisoning effect for metal catalysts, and subsequently treatment to inhibit the growth of sulfate reducing bacteria would increase the cost and complextity of operation process [179]. Finally, the precious metals used in metal catalytic reduction are mostly expensive, limiting its wide use 
in industry. To ensure the reproducibility and stability of metal catalysts is also another challenge.

\subsubsection{Biological degradation}

Biodegradation, unlike photolysis, leads to the disppearance of NDMA precursors, and will not form NDMA during disinfection, with complete degradation of NDMA. Compared with photolysis, the biodegradation speed is slower. However, biological degradation is still a great potential in removal of NDMA. The half-life of NDMA in lawn soil by biodegradation was 4-6 d [180] while those in silt soil were 11-39 d [181]. Under aerobic and anaerobic conditions, NDMA in soil and the water environment can be degraded by microorganisms in which the aerobic biodegradation rate is faster than anaerobic [175]. Zhou et al. [182] monitored NDMA in groundwater over $7 \mathrm{y}$ and found that about $90 \%$ of NDMA was degraded by microorganisms. Sharp et al. [183] used aerobic bacterial to deal with NDMA in 15 kinds of sewage, the removal rate is more than $50 \%$ within the $30 \mathrm{~d}$. Yifru et al. [184] found that some aquatic plants was able to absorb NDMA. NDMA has a high solubility in water and cultivating aquatic plants has more positive economic impacts and great potential to absorb NDMA. Chung et al. [131] studied the effect of the hydrogen matrix biofilm reactor on the removal of NDMA, which showed a high removal efficiency up to $96 \%$. The generation of $\mathrm{H}_{2}$ was considered as determinant factor affecting NDMA removal.

\section{Conclusions}

The NDMA has wide range of sources and high carcinogenic risk. It is important to evaluate and control its formation potential. The present work reviewed the NDMA formation and controlable methods. There are still some issues to address. For example, identifying the precursor of NDMA is important because the proportion of NDMA generated by DMA is small while research on NDMA formation by other precursors is relatively rare, especially on the DON and other DMA-containing materials. The mechanism for formation of NDMA in disinfection process is still to be further revealed because the existing mechanisms cannot completely explain the generation of NDMA. In the disinfection process, it is necessary to study new NDMA formation mechanisms. The migration and transformation of N-containing compounds in NDMA formation process are the current focus of interest, especially the role of DON on the formation of NDMA. The DOC, DON and other parameters, for example, disinfectant type and dosages, environmental conditions affecting the water source, have important impact on the NDMA formation potential, which requires timely on-line monitoring. Conventional methods are difficult to control NDMA. UV radiation and AOPs have good influence on the removal of NDMA, and the equipment is simple, but the higher operating cost limits its application. The AOPs with low energy consumption of hydroxyl radical are therefore expected to improve the degradation efficiency of NDMA. The use of metal reduction has some limitations and the cost is high, so it needs to further process. Microbial and plant treatments have certain potential. The coupling these proc- esses may be a better pathway to ensure removal of NDMA from water.

\section{Acknowledgments}

We acknowledge the financial support of the National Natural Science Foundation of China (No. 51408215), Natural Science Foundation of Hunan Province of China (No. 2018JJ2128), China Postdoctoral Science Foundation (No. 2017M622578) and Hunan Province Graduate research and innovation projects in China (CX2017B638).

\section{References}

1. Chang Y, Chen Q, Li N, et al. Development tendency of drinking water disinfection based on a bibliometrics analysis. Acta Sci. Circum. 2016;36:413-419.

2. Tokmak B, Capar G, Dilek FB, Yetis U. Trihalomethanes and associated potential cancer risks in the water supply in Ankara, Turkey. Environ. Res. 2004;96:345-352.

3. Chu W, Chu T, Du E, Yang D, Guo Y, Gao N. Increased formation of halomethanes during chlorination of chloramphenicol in drinking water by UV irradiation, persulfate oxidation, and combined UV/persulfate pre-treatments. Ecotoxicol. Environ. Saf. 2016;124:147-154.

4. Zhang TY, Lin YL, Xu B, et al. Identification and quantification of ineffective chlorine by $\mathrm{NaAsO}_{2}$ selective quenching method during drinking water disinfection. Chem. Eng. J. 2015;277:295-302.

5. Helbling DE, Vanbriesen JM. Free chlorine demand and cell survival of microbial suspensions. Water Res. 2007;41:4424-4434.

6. Fu J, Lee W, Coleman C, Nowack K, Carter J, Huang CH. Removal of disinfection byproduct (DBP) precursors in water by two-stage biofiltration treatment. Water Res. 2017;123:224-235.

7. Liu C, Olivares CI, Pinto AJ, et al. The control of disinfection byproducts and their precursors in biologically active filtration processes. Water Res. 2017;124:630-653.

8. Zhang Y, Chu W, Yao D, Yin D. Control of aliphatic halogenated DBP precursors with multiple drinking water treatment processes: Formation potential and integrated toxicity. J. Environ. Sci. 2017;58:322-330.

9. Zhang $\mathrm{Y}$, Chu W, Xu T, et al. Impact of pre-oxidation using $\mathrm{H}_{2} \mathrm{O}_{2}$ and ultraviolet $/ \mathrm{H}_{2} \mathrm{O}_{2}$ on disinfection byproducts generated from chlor(am)ination of chloramphenicol. Chem. Eng. J. 2017;317:112-118.

10. Zuo TH, Kristiana I, Busetti F, Linge KL, Joll CA. Organic chloramines in chlorine-based disinfected water systems: A critical review. J. Environ. Sci. 2017;58:2-18.

11. Donnermair MM, Blatchley ER 3rd. Disinfection efficacy of organic chloramines. Water Res. 2003;37:1557-1570.

12. Lee W, Westerhoff P. Formation of organic chloramines during water disinfection: Chlorination versus chloramination. Water Res. 2009;43:2233-2239.

13. Shen R, Andrews SA. Demonstration of 20 pharmaceuticals and personal care products (PPCPs) as nitrosamine precursors 
during chloramine disinfection. Water Res. 2011;45:944-952. 14. Lyon BA, Dotson AD, Linden KG, Weinberg HS. The effect of inorganic precursors on disinfection byproduct formation during UV-chlorine/chloramine drinking water treatment. Water Res. 2012;46:4653-4664.

15. Kanniganti R, Johnson JD, Ball LM, Charles MJ. Identification of compounds in mutagenic extracts of aqueous monochloraminated fulvic acid. Environ. Sci. Technol. 1992;26: 1998-2004.

16. Mitch WA, Sedlak DL. Formation of $N$-nitrosodimethylamine (NDMA) from dimethylamine during chlorination. Environ. Sci. Technol. 2002;36:588-595.

17. Choi J, Valentine RL. Formation of $N$-nitrosodimethylamine (NDMA) from reaction of monochloramine: A new disinfection by-product. Water Res. 2002;36:817-824.

18. Chu W, Gao N, Deng Y, Templeton MR, Yin D. Impacts of drinking water pretreatments on the formation of nitrogenous disinfection by-products. Bioresour. Technol. 2011; 102:11161-11166.

19. Xu B, Ye T, Li D, et al. Measurement of dissolved organic nitrogen in a drinking water treatment plant: Size fraction, fate, and relation to water quality parameters. Sci. Total Environ. 2011;409:1116-1122.

20. Uzun H, Kim D, Karanfil T. Seasonal and temporal patterns of NDMA formation potentials in surface waters. Water Res. 2015;69:162-172.

21. Zhang B, Xian Q, Gong T, Li Y, Li A, Feng J. DBPs formation and genotoxicity during chlorination of pyrimidines and purines bases. Chem. Eng. J. 2017;307:884-890.

22. Tian F, Xu B, Lin Y, et al. Chlor(am)ination of iopamidol: Kinetics, pathways and disinfection by-products formation. Chemosphere 2017;184:489-497.

23. Liu P, Farré MJ, Keller J, Gernjak W. Reducing natural organic matter and disinfection by-product precursors by alternating oxic and anoxic conditions during engineered short residence time riverbank filtration: A laboratory-scale column study. Sci. Total Environ. 2016;565:616-625.

24. Meng Y, Wang M, Guo B, et al. Characterization and C-, $\mathrm{N}$-disinfection byproduct formation of dissolved organic matter in MBR and anaerobic-anoxic-oxic (AAO) processes. Chem. Eng. J. 2017;315:243-250.

25. Zhou S, Zhu S, Shao Y, Gao N. Characteristics of C-, N-DBPs formation from algal organic matter: Role of molecular weight fractions and impacts of pre-ozonation. Water Res. 2015;72: 381-390.

26. Goslan EH, Krasner SW, Bower M, et al. A comparison of disinfection by-products found in chlorinated and chloraminated drinking waters in Scotland. Water Res. 2009;43:4698-4706.

27. Ersan MS, Ladner DA, Karanfil T. The control of $N$-nitrosodimethylamine, halonitromethane, and trihalomethane precursors by nanofiltration. Water Res. 2016;105:274-281.

28. Brown JL. N-Nitrosamines. Occup. Med. 1999;14:839-848.

29. Luo Q, Wang D, Wang Z. Occurrences of nitrosamines in chlorinated and chloraminated drinking water in three representative cities, China. Sci. Total Environ. 2012;437:219-225.

30. Souliotis VL, Henneman JR, Reed CD, et al. DNA adducts and liver DNA replication in rats during chronic exposure to $N$-nitrosodimethylamine (NDMA) and their relationships to the dose-dependence of NDMA hepatocarcinogenesis. Mutat. Res. Fund. Mol. M. 2002;500:75-87.

31. Charrois JWA, Arend MW, Froese KL, Hrudey SE. Detecting $N$-nitrosamines in drinking water at nanogram per liter levels using ammonia positive chemical ionization. Environ. Sci. Technol. 2004;38:4835-4841.

32. Wang W, Hu J, Yu J, Yang M. Determination of $N$-nitrosodimethylamine in drinking water by UPLC-MS/MS. J. Environ. Sci. 2010;22:1508-1512.

33. Liang C, Xu B, Xian SJ, Gao NY, Li DP, Tian FX. Detection of trace NDMA in drinking water by SPE/LC/MS/MS. China Water Wastewater 2009;25:82-85.

34. Mitch WA, Sharp JO, Trussell RR, Valentine RL, Alvarez-Cohen L, Sedlak DL. $N$-nitrosodimethylamine (NDMA) as a drinking water contaminant: A review. Environ. Eng. Sci. 2003;20:389-404.

35. Chu WH, Gao NY, Yang D. Classification and toxicological evaluation of newfound nitrogenous disinfection byproducts (N-DBPs) in drinking water. Modern Chem. Ind. 2009; 29:86-89.

36. Zhao YY, Boyd J, Hrudey SE, Li XF. Characterization of new nitrosamines in drinking water using liquid chromatography tandem mass spectrometry. Environ. Sci. Technol. 2006;40:7636-7641.

37. Li T, Xian Q, Sun C, Li A. The level and analysis of $N$-nitrosamines in waters. Environ. Chem. 2012;31:1767-1774.

38. Planas C, Palacios O, Ventura F, Rivera J, Caixach J. Analysis of nitrosamines in water by automated SPE and isotope dilution GC/HRMS: Occurrence in the different steps of a drinking water treatment plant, and in chlorinated samples from a reservoir and a sewage treatment plant effluent. Talanta 2008;76:906-913

39. Gerecke AC, Sedlak DL. Precursors of $N$-nitrosodimethylamine in natural waters. Environ. Sci. Technol. 2003;37:1331-1336.

40. Chen ZL, Yin SZ, Yang L, Liu T, Xu BB. N-nitrosodimethylamine: A new disinfection by-product in water. China Water Wastewater 2007;23:6-11.

41. He Y, Cheng H. Degradation of $N$-nitrosodimethylamine (NDMA) and its precursor dimethylamine (DMA) in mineral micropores induced by microwave irradiation. Water Res. 2016;94:305-314.

42. Zeng T, Mitch WA. Contribution of $N$-nitrosamines and their precursors to domestic sewage by greywaters and blackwaters. Environ. Sci. Technol. 2015;49:13158-13167.

43. Krauss M, Longrée P, Houtte EV, Cauwenberghs J, Hollender J. Assessing the fate of nitrosamine precursors in wastewater treatment by physicochemical fractionation. Environ. Sci. Technol. 2010;44:7871-7877.

44. Mamo J, Insa S, Monclús H, et al. Fate of NDMA precursors through an MBR-NF pilot plant for urban wastewater reclamation and the effect of changing aeration conditions. Water Res. 2016;102:383-393.

45. Wenhai C, Naiyun G. Formation and removal of nitrogenous disinfection by-products NDMA in drinking water. Acta Chim. Sinica 2009;72:388-393. 
46. Lü C, Liu Y, Wang Y, Zhong R. Theoretical studies on the $N$-nitrosodimethylamine formation from dimethylamine and nitrous acid. Acta Chim. Sinica 2007;65:1568-1572.

47. Chen ZL, Xu BB, Qi H, et al. Determination of trace nitrosodimethylamine in water by high performance liquid chromatogram. China Water Wastewater 2007;23:84-87.

48. Sun Z, Liu YD, Zhong RG. Theoretical investigation of $N$-nitrosodimethylamine formation from nitrosation of trimethylamine. J. Phys. Chem. A 2010;114:455-465.

49. Choi J, Valentine RL. $N$-nitrosodimethylamine formation by free-chlorine-enhanced nitrosation of dimethylamine. Environ. Sci. Technol. 2003;37:4871-4876.

50. Andrzejewski P, Kasprzykhordern B, Nawrocki J. N-nitrosodimethylamine (NDMA) formation during ozonation of dimethylamine-containing waters. Water Res. 2008;42:863-870.

51. Choi J, Valentine RL. A kinetic model of $N$-nitrosodimethylamine (NDMA) formation during water chlorination/chloramination. Water Sci. Technol. 2002;46:65-71.

52. Zhang QQ, Pan SL, Zhang Y, Yang M, An W. Estimation of health risk and enaction of safety standards of $\mathrm{N}$-nitrosodimethylamine (NDMA) in drinking waters in China. Environ. Sci. 2017;38:2747-2753.

53. Haiyan W, Xiuquan S, Ming Q, et al. The exposure level of nitrosamines disinfection by-products in drinking water of China: A Meta analysis. J. Zunyi Med. Univ. 2017;40: 278-284.

54. Yang L, Chen Z, Shen J, et al. Reinvestigation of the nitrosamine-formation mechanism during ozonation. Environ. Sci. Technol. 2009;43:5481-5487.

55. Schreiber IM, Mitch WA. Influence of the order of reagent addition on NDMA formation during chloramination. Environ. Sci. Technol. 2005;39:3811-3818.

56. Schreiber IM, Mitch WA. Nitrosamine formation pathway revisited: The importance of chloramine speciation and dissolved oxygen. Environ. Sci. Technol. 2006;40:6007-6014.

57. Park SH, Padhye LP, Wang P, Cho M, Kim JH, Huang CH. $\mathrm{N}$-nitrosodimethylamine (NDMA) formation potential of amine-based water treatment polymers: Effects of in situ chloramination, breakpoint chlorination, and pre-oxidation. J. Hazard. Mater. 2015;282:133-140.

58. Roux JL, Gallard H, Croué JP. Chloramination of nitrogenous contaminants (pharmaceuticals and pesticides): NDMA and halogenated DBPs formation. Water Res. 2011;45:3164-3174.

59. Lee H, Lee E, Lee CH, Lee K. Degradation of chlorotetracycline and bacterial disinfection in livestock wastewater by ozone-based advanced oxidation. J. Ind. Eng. Chem. 2011;17: 468-473.

60. Gerrity D, Gamage S, Holady JC, et al. Pilot-scale evaluation of ozone and biological activated carbon for trace organic contaminant mitigation and disinfection. Water Res. 2011;45: 2155-2165.

61. Silva GHR, Daniel LA, Bruning H, Rulkens WH. Anaerobic effluent disinfection using ozone: Byproducts formation. Bioresour. Technol. 2010;101:6992-6997.

62. Jung YJ, Oh BS, Kang JW. Synergistic effect of sequential or combined use of ozone and UV radiation for the disinfection of Bacillus subtilis spores. Water Res. 2008;42:
1613-1621.

63. Kitazaki S, Tanaka A, Hayashi N. Sterilization of narrow tube inner surface using discharge plasma, ozone, and UV light irradiation. Vacuum 2014;110:217-220.

64 Zhou XJ, Guo WQ, Yang SS, Zheng HS, Ren NQ. Ultrasonic-assisted ozone oxidation process of triphenylmethane dye degradation: Evidence for the promotion effects of ultrasonic on malachite green decolorization and degradation mechanism. Bioresour. Technol. 2013;128:827-830.

65. Cardoso JC, Bessegato GG, Zanoni MVB. Efficiency comparison of ozonation, photolysis, photocatalysis and photoelectrocatalysis methods in real textile wastewater decolorization. Water Res. 2016;98:39-46.

66. Turhan K, Durukan I, Ozturkcan SA, Turgut Z. Decolorization of textile basic dye in aqueous solution by ozone. Dyes Pigm. 2012;92:897-901.

67. Ham JE, Wells JR. Surface chemistry of a pine-oil cleaner and other terpene mixtures with ozone on vinyl flooring tiles. Chemosphere 2011;83:327-333.

68. Oya M, Kosaka K, Asami M, Kunikane S. Formation of N-nitrosodimethylamine (NDMA) by ozonation of dyes and related compounds. Chemosphere 2008;73:1724-1730.

69. Duffy EF, Touati FA, Kehoe SC, et al. A novel $\mathrm{TiO}_{2}$-assisted solar photocatalytic batch-process disinfection reactor for the treatment of biological and chemical contaminants in domestic drinking water in developing countries. Solar Energ. 2004;77:649-655.

70. Zhao YY, Boyd JM, Woodbeck M, et al. Formation of $N$-nitrosamines from eleven disinfection treatments of seven different surface waters. Environ. Sci. Technol. 2008;42:4857-4862.

71. Zhang A, Li Y, Song Y, Lv J, Yang J. Characterization of pharmaceuticals and personal care products as $\mathrm{N}$-nitrosodimethylamine precursors during disinfection processes using free chlorine and chlorine dioxide. J. Hazard. Mater. 2014;276:499-509.

72. Mitch WA, Gerecke AC, Sedlak DL. A N-nitrosodimethylamine (NDMA) precursor analysis for chlorination of water and wastewater. Water Res. 2003;37:3733-3741.

73. Chen WH, Young TM. NDMA formation during chlorination and chloramination of aqueous diuron solutions. Environ. Sci. Technol. 2008;42:1072-1077.

74. Charrois JW, Hrudey SE. Breakpoint chlorination and free-chlorine contact time: Implications for drinking water $N$-nitrosodimethylamine concentrations. Water Res. 2007;41: 674-682.

75. Farré MJ, Döderer K, Hearn L, Poussade Y, Keller J, Gernjak W. Understanding the operational parameters affecting NDMA formation at advanced water treatment plants. J. Hazard. Mater. 2011;185:1575-1581.

76. Changha L, Carsten S, Jeyong Y. Oxidation of $N$-nitrosodimethylamine (NDMA) precursors with ozone and chlorine dioxide: Kinetics and effect on NDMA formation potential. Environ. Sci. Technol. 2007;41:2056-2063.

77. Seid MG, Cho K, Lee C, Park HM, Hong SW. Nitrite ion mitigates the formation of $\mathrm{N}$-nitrosodimethylamine (NDMA) during chloramination of ranitidine. Sci. Total Environ. 2018;633:352-359. 
78. Selbes M, Kim D, Karanfil T. The effect of pre-oxidation on NDMA formation and the influence of $\mathrm{pH}$. Water Res. 2014;66:169-179.

79. Shen R, Andrews SA. Formation of NDMA from ranitidine and sumatriptan: The role of pH. Water Res. 2013;47:802-810.

80. Hatt JW, Lamy C, Germain E, Tupper M, Judd SJ. NDMA formation in secondary wastewater effluent. Chemosphere 2013;91:83-87.

81. Andrzejewski P, Nawrocki J. N-nitrosodimethylamine formation during treatment with strong oxidants of dimethylamine containing water. Water Sci. Technol. 2007;56:125-131.

82. Andrzejewski P, Kasprzyk-Hordern B, Nawrocki J. The hazard of $N$-nitrosodimethylamine (NDMA) formation during water disinfection with strong oxidants. Desalination 2005;176:37-45.

83. Chen Z, Valentine RL. Modeling the formation of $N$-nitrosodimethylamine (NDMA) from the reaction of natural organic matter (NOM) with monochloramine. Environ. Sci. Technol. 2006;40:7290-7297.

84. Lv J, Wang L, Song Y, Li Y. N-nitrosodimethylamine formation from ozonation of chlorpheniramine: Influencing factors and transformation mechanism. J. Hazard. Mater. 2015;299:584-594.

85. Marti EJ, Pisarenko AN, Peller JR, Dickenson ER. $N$-nitrosodimethylamine (NDMA) formation from the ozonation of model compounds. Water Res. 2015;72:262-270.

86. Sgroi M, Roccaro P, Oelker GL, Snyder SA. N-nitrosodimethylamine (NDMA) formation at an indirect potable reuse facility. Water Res. 2015;70:174-183.

87. Sgroi M, Roccaro P, Oelker G, Snyder SA. N-nitrosodimethylamine (NDMA) formation during ozonation of wastewater and water treatment polymers. Chemosphere 2016;144: 1618-1623.

88. Lim S, Lee W, Na S, Shin J, Lee Y. N-nitrosodimethylamine (NDMA) formation during ozonation of $\mathrm{N}, \mathrm{N}$-dimethylhydrazine compounds: Reaction kinetics, mechanisms, and implications for NDMA formation control. Water Res. 2016;105:119-128.

89. $\mathrm{Hu} \mathrm{H}$, Jiang $\mathrm{C}$, Ma $\mathrm{H}$, et al. Removal characteristics of DON in pharmaceutical wastewater and its influence on the $\mathrm{N}$-nitrosodimethylamine formation potential and acute toxicity of DOM. Water Res. 2017;109:114-121.

90. Boyd JM, Hrudey SE, Li XF, Richardson SD. Solid-phase extraction and high-performance liquid chromatography mass spectrometry analysis of nitrosamines in treated drinking water and wastewater. TrAC Trend. Anal. Chem. 2011;30:1410-1421.

91. Kemper JM, Walse SS, Mitch WA. Quaternary amines as nitrosamine precursors: A role for consumer products? Environ. Sci. Technol. 2010;44:1224-1231.

92. Liu C, Olivares CI, Pinto AJ, et al. The control of disinfection byproducts and their precursors in biologically active filtration processes. Water Res. 2017;124:630-653.

93. Song Y, Breider F, Ma J, von Gunten U. Nitrate formation during ozonation as a surrogate parameter for abatement of micropollutants and the $N$-nitrosodimethylamine (NDMA) formation potential. Water Res. 2017;122:246-257.

94. Mitch WA, Sedlak DL. Factors controlling nitrosamine formation during wastewater chlorination. Water Sci. Technol. Water Supply 2002;2:191-198.
95. Wilczak A, Assadi-Rad A, Lai HH, et al. Formation of NDMA in chloraminated water coagulated with DADMAC cationic polymer. J. Am. Water Works Assoc. 2003;95:94-106.

96. Shen R, Andrews SA. Demonstration of 20 pharmaceuticals and personal care products (PPCPs) as nitrosamine precursors during chloramine disinfection. Water Res. 2011;45:944-952.

97. Mitch WA, Sedlak DL. Characterization and fate of $N$-nitrosodimethylamine precursors in municipal wastewater treatment plants. Environ. Sci. Technol. 2004;38:1445-1454.

98. Chen Z, Valentine RL. Formation of $N$-nitrosodimethylamine (NDMA) from humic substances in natural water. Environ. Sci. Technol. 2007;41:6059-6065.

99. Li L, Gao N, Deng Y, Yao J, Zhang K. Characterization of intracellular \& extracellular algae organic matters (AOM) of Microcystis aeruginosa and formation of AOM-associated disinfection byproducts and odor \& taste compounds. Water Res. 2012;46:1233-1240.

100. Ma C, Pei H, Hu W, Wang Y, Xu H, Jin Y. The enhanced reduction of $\mathrm{C}$ - and $\mathrm{N}$-DBP formation in treatment of source water containing Microcystis aeruginosa using a novel CTSAC composite coagulant. Sci. Total Environ. 2017;579: 1170-1178.

101. Zhang H, Andrews SA. Factors affecting catalysis of copper corrosion products in NDMA formation from DMA in simulated premise plumbing. Chemosphere 2013;93:2683-2689.

102. Gan X, Karanfil T, Kaplan Bekaroglu SS, Shan J. The control of N-DBP and C-DBP precursors with MIEX ${ }^{\circledR}$. Water Res. 2013;47:1344-1352.

103. Luo XH, Clevenger TE, Deng BL. Role of NOM in the formation of $\mathrm{N}$-nitrosodimethylamine (NDMA) in surface waters. In: Abstracts of papers of the American chemical society. 1155 16th st, NW, Washington D.C. 20036 USA: Amer Chemical Soc; 2005. p. U848-U848.

104. Pehlivanoglu-Mantas E, Sedlak DL. Measurement of dissolved organic nitrogen forms in wastewater effluents: Concentrations, size distribution and NDMA formation potential. Water Res. 2008;42:3890-3898.

105. Lee W, Westerhoff P, Croué JP. Dissolved organic nitrogen as a precursor for chloroform, dichloroacetonitrile, $\mathrm{N}$-nitrosodimethylamine, and trichloronitromethane. Environ. Sci. Technol. 2007;41:5485-5490.

106. Pehlivanoglu-Mantas E, Hawley EL, Deeb RA, Sedlack DL. Formation of nitrosodimethylamine (NDMA) during chlorine disinfection of wastewater effluents prior to use in irrigation systems. Water Res. 2006;40:341-347.

107. Hu H, Ma H, Ding L, et al. Concentration, composition, bioavailability, and $\mathrm{N}$-nitrosodimethylamine formation potential of particulate and dissolved organic nitrogen in wastewater effluents: A comparative study. Sci. Total Environ. 2016;569-570:1359-1368.

108. Bazri MM, Martijn B, Kroesbergen J, Mohseni M. Impact of anionic ion exchange resins on NOM fractions: Effect on N-DBPs and C-DBPs precursors. Chemosphere 2016;144: 1988-1995.

109. Zhang H, Zhang K, Jin H, Gu L, Yu X. Variations in dissolved organic nitrogen concentration in biofilters with different 
media during drinking water treatment. Chemosphere 2015;139:652-658.

110. Michael-Kordatou I, Michael C, Duan X, et al. Dissolved effluent organic matter: Characteristics and potential implications in wastewater treatment and reuse applications. Water Res. 2015;77:213-248.

111. Lee W, Westerhoff P, Esparza-Soto M. Occurrence and removal of dissolved organic nitrogen in US water treatment plants. J. Am. Water Works Assoc. 2006;98:102-110.

112. Qiao CG, Wei QS, Wang D, Yang M, Wei Q, Li MJ. Molecular weight distribution and removal characters of DOM in the typical source water in south of China. Acta Sci. Circum. 2007;27:195-200.

113. Acero JL, Real FJ, Benitez FJ, Gonzalez M. Kinetics of reactions between chlorine or bromine and the herbicides diuron and isoproturon. J. Chem. Technol. Biotechnol. 2007;82:214-222

114. Mascolo G, Lopez A, James H, Fielding M. By-products formation during degradation of isoproturon in aqueous solution. II: Chlorination. Water Res. 2001;35:1705-1713.

115. Fuxiang T, Bin X, Lang Q, et al. Influence of bromide ions upon chlorination characteristics of chlortoluron as precursor of NDMA. J. Tongji Univ. 2014;42:272-277.

116. von Gunten U, Salhi E, Schmidt CK, Arnold WA. Kinetics and mechanisms of $N$-nitrosodimethylamine formation upon ozonation of $\mathrm{N}, \mathrm{N}$-dimethylsulfamide-containing waters: Bromide catalysis. Environ. Sci. Technol. 2010;44: 5762-5768.

117. Padhye L, Wang P, Karanfil T, Huang CH. Unexpected role of activated carbon in promoting transformation of secondary amines to $\mathrm{N}$-nitrosamines. Environ. Sci. Technol. 2010;44:4161-4168.

118. Kodamatani H, Lwaya Y, Saga M, et al. Ultra-sensitive HPLC-photochemical reaction-luminol chemiluminescence method for the measurement of secondary amines after nitrosation. Anal. Chim. Acta 2017;952:50-58.

119, Farré MJ, Insa S, Mamo J, Barceló D. Determination of $15 \mathrm{~N}$-nitrosodimethylamine precursors in different water matrices by automated on-line solid-phase extraction ultra-high-performance-liquid chromatography tandem mass spectrometry. J. Chromatogr. A 2016;1458:99-111.

120. Herrmann SS, Granby K, Duedahl-Olesen L. Formation and mitigation of $N$-nitrosamines in nitrite preserved cooked sausages. Food Chem. 2015;174:516-526.

121. Farajzadeh MA, Abbaspour M. Development of a new sample preparation method based on liquid-liquid-liquid extraction combined with dispersive liquid-liquid microextraction and its application on unfiltered samples containing high content of solids. Talanta 2017;174:111-121.

122. Farajzadeh MA, Yadeghari A, Khoshmaram L. Combination of dispersive solid phase extraction and dispersive liquid-liquid microextraction for extraction of some aryloxy pesticides prior to their determination by gas chromatography. Microchem. J. 2017;131:182-191.

123. Wen Hai C, Nai Yun G, Shigu Z. Advance in analytical techniques of disinfection by-products NDMA in drinking water. Chem. Ind. Eng. Prog. 2008;27:1512-1515.
124. Kosaka K, Asami M, Konno Y, Oya M, Kunikane S. Identification of antiyellowing agents as precursors of $\mathrm{N}$-nitrosodimethylamine production on ozonation from sewage treatment plant influent. Environ. Sci. Technol. 2009; 43:5236-5241.

125. Grebel JE, Young CC, Suffet IH. Solid-phase microextraction of N-nitrosamines. J. Chromatogr. A 2006;1117:11-18.

126. Zhao YY, Boyd J, Hrudey SE, Li XF. Characterization of new nitrosamines in drinking water using liquid chromatography tandem mass spectrometry. Environ. Sci. Technol. 2006;40:7636-7641.

127. Krauss M, Hollender J. Analysis of nitrosamines in wastewater: Exploring the trace level quantification capabilities of a hybrid linear ion trap/orbitrap mass spectrometer. Anal. Chem. 2008;80:834-842.

128. Qiu Ju Z, Zu Peng G, Ming Zu L. Determination of seven $N$-nitrosamine compounds by HS-SPME-GC-MS. Chinese J. Health Lab. Technol. 2009;19:1234-1236.

129. Fine DH, Rounbehler DP, Rounbehler A, et al. Determination of dimethylnitrosamine in air, water, and soil by thermal energy analysis: Measurements in Baltimore, Md. Environ. Sci. Technol. 1977;11:581-584.

130. Lee C, Lee Y, Schmidt C, Yoon J, Von Gunten U. Oxidation of suspected $N$-nitrosodimethylamine (NDMA) precursors by ferrate (VI): Kinetics and effect on the NDMA formation potential of natural waters. Water Res. 2008;42:433-441.

131. Chung J, Ahn CH, Chen Z, Rittmann BE. Bio-reduction of $\mathrm{N}$-nitrosodimethylamine (NDMA) using a hydrogen-based membrane biofilm reactor. Chemosphere 2008; 70:516-520.

132. Plumlee $\mathrm{MH}$, Reinhard M. Photochemical attenuation of $N$-nitrosodimethylamine (NDMA) and other nitrosamines in surface water. Environ. Sci. Technol. 2007;41:6170-6176.

133. Hanigan D, Ferrer I, Thurman EM, Herckes P, Westerhoff P. LC/QTOF-MS fragmentation of $N$-nitrosodimethylamine precursors in drinking water supplies is predictable and aids their identification. J. Hazard. Mater. 2017;323:18-25.

134. Hong Y, Kim KH, Sang BI, Kim H. Simple quantification method for $N$-nitrosamines in atmospheric particulates based on facile pretreatment and GC-MS/MS. Environ. Pollut. 2017;226:324-334.

135. Fujioka T, Takeuchi H, Tanaka H, Nghiem LD, Ishida KP, Kodamatani H. A rapid and reliable technique for $\mathrm{N}$-nitrosodimethylamine analysis in reclaimed water by HPLCphotochemical reaction-chemiluminescence. Chemosphere 2016;161:104-111.

136. Hu CW, Shih YM, Liu HH, Chiang YC, Chen CM, Chao MR. Elevated urinary levels of carcinogenic $N$-nitrosamines in patients with urinary tract infections measured by isotope dilution online SPE LC-MS/MS. J. Hazard. Mater. 2016;310:207-216.

137. Kodamatani H, Yamasaki H, Sakaguchi T, et al. Rapid method for monitoring $N$-nitrosodimethylamine in drinking water at the $\mathrm{ng} / \mathrm{L}$ level without pre-concentration using high-performance liquid chromatography-chemiluminescence detection. J. Chromatogr. A 2016;1460:202-206.

138. Wang C, Zhang X, Wang J, Chen C. Characterization of 
dissolved organic matter as $N$-nitrosamine precursors based on hydrophobicity, molecular weight and fluorescence. $J$. Environ. Sci. 2013;25:85-95.

139. Lu C, Li S, Gong S, Yuan S, Yu X. Mixing regime as a key factor to determine DON formation in drinking water biological treatment. Chemosphere 2015;139:638-643.

140. Liu B, Gu L, Yu X, Yu G, Zhang H, Xu J. Dissolved organic nitrogen (DON) profile during backwashing cycle of drinking water biofiltration. Sci. Total Environ. 2012;414:508-514.

141. Xu B, Li DP, Li W, et al. Measurements of dissolved organic nitrogen (DON) in water samples with nanofiltration pretreatment. Water Res. 2010;44:5376-5384.

142. Lee S, Lueptow RM. Toward a reverse osmosis membrane system for recycling space mission wastewater. Life Support Biosph. Sci. 2000;7:251-261.

143. Hu H, Ding L, Geng J, Huang H, Xu K, Ren H. Effect of coagulation on dissolved organic nitrogen (DON) bioavailability in municipal wastewater effluents. J. Environ. Chem. Eng. 2016;4:2536-2544.

144. Zhu G, Wang Q, Yin J, et al. Toward a better understanding of coagulation for dissolved organic nitrogen using polymeric zinc-iron-phosphate coagulant. Water Res. 2016;100: 201-210.

145. Arnaldos M, Pagilla K. Effluent dissolved organic nitrogen and dissolved phosphorus removal by enhanced coagulation and microfiltration. Water Res. 2010;44:5306-5315.

146. Lee W, Westerhoff P. Dissolved organic nitrogen removal during water treatment by aluminum sulfate and cationic polymer coagulation. Water Res. 2006;40:3767-3774.

147. Wei LI, Bin XU, Xia SJ, et al. Characteristics of DON and NDMA formation potential in water treatment. China Water Wastewater 2009;25:35-38.

148. Tomaszewska M, Mozia S. Removal of organic matter from water by PAC/UF system. Water Res. 2002;36:4137-4143.

149. Yoon Y, Lueptow RM. Removal of organic contaminants by RO and NF membranes. J. Membrane Sci. 2005;261: 76-86.

150. Lee S, Lueptow RM. Reverse osmosis filtration for space mission wastewater: Membrane properties and operating conditions. J. Membrane Sci. 2001;182:77-90.

151. Charrois JWA, Hrudey SE. Breakpoint chlorination and free-chlorine contact time: Implications for drinking water $N$-nitrosodimethylamine concentrations. Water Res. 2007; 41:674-682.

152. Ventanas S, Ruiz J. On-site analysis of volatile nitrosamines in food model systems by solid-phase microextraction coupled to a direct extraction device. Talanta 2006;70: 1017-1023.

153. Yoon S, Nakada N, Tanaka H. Occurrence and removal of NDMA and NDMA formation potential in wastewater treatment plants. J. Hazard. Mater. 2011;190:897-902.

154. Chen HW, Chen CY, Wang GS. Performance evaluation of the $\mathrm{UV} / \mathrm{H}_{2} \mathrm{O}_{2}$ process on selected nitrogenous organic compounds: Reductions of organic contents vs. corresponding C-, N-DBPs formations. Chemosphere 2011;85:591-597.

155. Kommineni S, Ela WP, Arnold RG, Huling SG, Hester BJ, Betterton EA. NDMA treatment by sequential GAC adsorp- tion and Fenton-driven destruction. Environ. Eng. Sci. 2003;20:361-373

156. Dai XD, Bao XC, Zhu YJ, et al. Removal of $N$-nitrosodimethylamine from water by modified activated carbons. Carbon Tech. 2010;29:11-15.

157. Plumlee MH, López-Mesas M, Heidlberger A, Ishida KP, Reinhard M. $N$-nitrosodimethylamine (NDMA) removal by reverse osmosis and UV treatment and analysis via LC-MS/MS. Water Res. 2007;42:347-355.

158. Steinle-Darling E, Zedda M, Plumlee MH, Ridgway HF, Reinhard M. Evaluating the impacts of membrane type, coating, fouling, chemical properties and water chemistry on reverse osmosis rejection of seven nitrosoalklyamines, including NDMA. Water Res. 2007;41:3959-3967.

159. Stefan MI, Bolton JR. UV direct photolysis of $N$-nitrosodimethylamine (NDMA): Kinetic and product study. Helv. Chim. Acta 2015;85:1416-1426.

160. Swaim P, Royce A, Smith T, Maloney T, Ehlen D, Carter B. Effectiveness of UV advanced oxidation for destruction of micro-pollutants. Ozone Sci. Eng. 2008;30:34-42.

161. Kwon BG, Kim JO, Namkung KC. The formation of reactive species having hydroxyl radical-like reactivity from UV photolysis of $N$-nitrosodimethylamine (NDMA): Kinetics and mechanism. Sci. Total Environ. 2012;437:237-244.

162. Lee M, Lee Y, Soltermann F, von Gunten U. Analysis of $\mathrm{N}$-nitrosamines and other nitro(so) compounds in water by high-performance liquid chromatography with post-column UV photolysis/Griess reaction. Water Res. 2013;47: 4893-4903.

163. Sun Z, Zhang C, Zhao X, Chen J, Zhou Q. Efficient photoreductive decomposition of $N$-nitrosodimethylamine by UV/iodide process. J. Hazard. Mater. 2016;329:185-192.

164. Lee C, Choi W, Kim YG, Yoon J. UV photolytic mechanism of $N$-nitrosodimethylamine in water: Dual pathways to methylamine versus dimethylamine. Environ. Sci. Technol. 2005;39:2101-2106.

165. Lee C, Choi W, Yoon J. UV photolytic mechanism of $N$-nitrosodimethylamine in water: Roles of dissolved oxygen and solution pH. Environ. Sci. Technol. 2005;39:9702-9709.

166. Sharpless CM, Linden KG. Experimental and model comparisons of low- and medium-pressure $\mathrm{Hg}$ lamps for the direct and $\mathrm{H}_{2} \mathrm{O}_{2}$ assisted UV photodegradation of $\mathrm{N}$-nitrosodimethylamine in simulated drinking water. Environ. Sci. Technol. 2003;37:1933-1940.

167. Xu BB, Chen ZL, Qi F, Ma J. Efficiency of photodecomposition of trace NDMA in water by UV irradiation. Environ. Sci. 2008;29:1908-1913.

168. Fan L, Yang X, Chen S, et al. Influence of light and temperature on degradation of $N$-nitrosodimethylamine and $N$-nitrosodiethylamine. South China Fish. Sci. 2009;5:53-58.

169. Legrini O, Oliveros E, Braun AM. Photochemical processes for water treatment. Chem. Rev. 1993;93:671-698.

170. Hiramoto K, Ryuno Y, Kikugawa K. Decomposition of $N$-nitrosamines, and concomitant release of nitric oxide by Fenton reagent under physiological conditions. Mutat. Res. Genet. Toxicol. Environ. Mutagen. 2002;520:103-111.

171. Lee C, Yoon J, Von Gunten U. Oxidative degradation of 
$\mathrm{N}$-nitrosodimethylamine by conventional ozonation and the advanced oxidation process ozone/hydrogen peroxide. Water Res. 2006;41:581-590.

172. Huang LX, Shen JM, Xu BB, Chen ZL. Study on photodegradation of NDMA using $\mathrm{UV} / \mathrm{H}_{2} \mathrm{O}_{2}$ process. China Water Wastewater 2010;26:104-108.

173. Xu BB, Chen ZL, Qi F, Yang L, Huang LX. Control on products of NDMA degradation by $\mathrm{UV} / \mathrm{O}_{3}$. Huanjing Kexue 2008;29:3421-3427.

174. Liang S, Min JH, Davis MK, Greenn JF, Remer DS. Use of pulsed-UV processes to destroy NDMA. J. Am. Water Works Assoc. 2003;95:121-131.

175. Frierdich AJ, Shapley JR, Strathmann TJ. Rapid reduction of $\mathrm{N}$-nitrosamine disinfection byproducts in water with hydrogen and porous nickel catalysts. Environ. Sci. Technol. 2008;42:262-269

176. Gui L, Gillham RW, Odziemkowski MS. Reduction of N-nitrosodimethylamine with granular iron and nickel-enhanced iron. 1. Pathways and kinetics. Environ. Sci. Technol. 2000;34:3489-3494.

177. Odziemkowski MS, Gui L, Gillham RW. Reduction of $N$-nitrosodimethylamine with granular iron and nickel-enhanced iron. 2. Mechanistic studies. Environ. Sci. Technol. 2000;34:3495-3500.
178. Davie MG, Reinhard M, Shapley JR. Metal-catalyzed reduction of $N$-nitrosodimethylamine with hydrogen in water. Environ. Sci. Technol. 2006;40:7329-7335.

179. Davie MG, Shih K, Pacheco FA, Leckie JO, Reinhard M. Palladium-indium catalyzed reduction of $\mathrm{N}$-nitrosodimethylamine: Indium as a promoter metal. Environ. Sci. Technol. 2008;42:3040-3046.

180. Yang WC, Gan J, Liu WP, Green R. Degradation of $N$-nitrosodimethylamine (NDMA) in landscape soils. J. Environ. Qual. 2005;34:336-341.

181. Mallik MA, Tesfai K. Transformation of nitrosamines in soil and in vitro by soil microorganisms. Bull. Environ. Contam. Toxicol. 1981;27:115-121.

182. Zhou Q, Mccraven S, Garcia J, Gasca M, Johnson TA, Motzer WE. Field evidence of biodegradation of $N$-nitrosodimethylamine (NDMA) in groundwater with incidental and active recycled water recharge. Water Res. 2009;43:793-805.

183. Sharp JO, Wood TK, Alvarezcohen L. Aerobic biodegradation of $N$-nitrosodimethylamine (NDMA) by axenic bacterial strains. Biotechnol. Bioeng. 2005;89:608-618.

184. Yifru DD, Nzengung VA. Uptake of $N$-nitrosodimethylamine (NDMA) from water by phreatophytes in the absence and presence of perchlorate as a co-contaminant. Environ. Sci. Technol. 2006;40:7374-7380. 